\title{
UMA APRESENTAÇÃO DIFERENTE: Memória e Luto em Tempos de Pandemia
}

Esta apresentação, diferentemente das outras, funcionará como um registro, como uma memória pública e como um grito que ecoa o luto que marcou e marca fundo a lembrança do tempo de muita gente. No momento em que escrevo esta apresentação, no dia 31 de agosto de 2021, o Brasil se aproxima de 580 mil mortes decorrentes da pandemia da Covid-19, e o mundo chega à marca de 4,5 milhões de vidas perdidas para a doença. A morte está por todos os lados e impõe diariamente a sua presença, desnudando de modo escrachado a finitude e a fragilidade que constitui nossa existência humana. Quase todos nós perdemos alguém. Amigos, pais e mães, filhos, alunos, colegas, íntimos ou distantes. Todos fomos tomados pela morte em excesso, como evento cotidiano para além do normal, como fato pura e simplesmente biológico, mas também como fato trágico e, portanto, existencial e determinante na condução de nossas próprias trajetórias. Fomos emparedados pela morte de um modo diferente na pandemia. A morte foi naturalizada e desdenhada por governos negacionistas e seu luto banalizado, neutralizado. A potência coletiva e pública que a morte sempre causou, pois ela sempre chega, foi aprisionada e relegada à dor íntima, vivida nos enterros sem corpos e nos lutos insuportavelmente individuais. Todos podemos portar o vírus, qualquer um pode transmiti-lo, desconfiamos de todos, obrigamos todos a tomarem a vacina. A morte não é, definitivamente, uma preocupação privada. Tornou-se um problema público e um problema do mundo.

Em seu clássico livro $O$ homem diante da morte, o historiador Ariès (2014) refere que a relação do homem com a morte se desenvolveu, no Ocidente, de três maneiras distintas. A primeira, durante os primeiros tempos da Idade Média, trata a morte como domada, como algo que chegará a todos indistintamente e sem precipitação e que levará o bom cristão ao encontro do Pai. A segunda, por volta do século 12, decorre da importância que o homem atribui a sua existência, deflagrando a ideia de uma vivência mais dramática da morte, pois passa a configurar em momento de julgamento individual de cada um pelas escolhas mundanas. O juízo final faz da morte o momento do julgamento da biografia individual da vida terrena. A terceira forma de relação com a morte lhe atribui uma posição de interdito, de escondimento da morte do outro. A morte, na modernidade, é a separação de quem se ama, é perda afetiva e é a dor da falta. A morte antes aceita é agora uma morte que separa, que descontinua, que faz doer, que tem relação com afeto e amor. Ocorre que agora a morte ocupa outro lugar e é sentida noutra dimensão, é vivenciada sozinha e as famílias sentem-se obrigadas, em certa medida, a evitar maiores manifestações públicas de sua dor. A Modernidade quase proíbe o luto fora da intimidade. O luto envergonhado e solitário parece ser o único recurso possível na Modernidade. Parece até que estamos proibidos de ficar comovidos pela morte dos outros. Evidência disso é o fato de que dois dias são, segundo a Consolidação das Leis do Trabalho, suficientes para que o empregado dê conta de administrar o seu luto (como se isso fosse possível) e voltar à vida profissional, agora com seus mortos a tiracolo, cuja ausência deve ser sentida nas horas vagas. De fato, se a morte está em todos os lugares, então ela está, também, em lugar nenhum. Quem sente, porém, a "ausência presente" da morte todos os dias pela perda "dos seus", sabe que ela está e sempre estará lá, num horizonte enuviado que traz a lembrança lancinante de tempos difíceis. 


\section{Democracia}

Em tempos de pandemia, em que a morte povoa nosso cotidiano diariamente, as instituições públicas deveriam dar a importância que de fato a morte passou a ocupar como evento público, como acontecimento social que repercute. Ao desdenhar da morte, os governos negacionistas desdenham do próprio luto, da possibilidade de a vida dos vivos suportarem a dor das rupturas no processo de produzir memória. Ao negarem a morte repentina e fora do tempo esperado negam a vida daqueles que a carregam. Em guerras e pandemias a morte é recolocada como um tema público e o seu luto deveria ser encarado do mesmo modo, como um acontecimento doloroso que compromete a todos com a morte dos outros. O luto não pode ser neutralizado, ele precisa ser vivido em seu próprio tempo e intensamente.

Viver o luto, com todos os pesos e durezas com que ele se apresenta, é condição de possibilidade de futuro, de continuidade de uma vida destravada que produz memória sem aprisionar. Essa travessia, no entanto, é muito difícil. Chimamanda Adichie (2020, p. 3), ao descrever a dor pela perda repentina do pai em decorrência de complicações renais em seu Notas sobre o luto, destaca que o "luto é uma forma cruel de aprendizado. Você aprende como ele pode ser pouco suave, raivoso. Aprende como os pêsames podem soar rasos. Aprende quanto do luto tem a ver com palavras, com a derrota das palavras e com a busca das palavras".

O Brasil precisa compreender o tamanho de suas perdas. Milhares de famílias enlutadas terão jornadas difíceis pela frente. É muito importante que se construa uma memória pública em torno dessas perdas antes de se desligar o passado. Por fim, gostaria de registrar uma homenagem especial à família do nosso aluno da primeira turma do Doutorado, Miguel Argemiro Soares Garaialdi, que infelizmente faleceu em decorrência da Covid-19 no ano de 2021. A forma de homenagear a todos é resistir e lutar contra as práticas e ações políticas que tratam a vida com indiferença e desprezo. Eis um bom compromisso para ligar o futuro.

ljuí/RS, 31 de agosto de 2021.

Doglas Lucas 